\title{
An Africanised and Gender Sensitive Curriculum as a Social Justice and Educational Human Right for South Africans
}

\author{
Thenjiwe Meyiwa \\ ORCID iD: $\underline{\text { http://orcid.org/0000-0001-9516-5470 }}$
}

Madoda Cekiso

ORCID iD: http://orcid.org/0000-0001-7681-077X

\section{Abstract}

The advent of the democratic dispensation in South Africa dismantled an education system that was divided into several subsystems along racial and ethnic-linguistic lines, which had transpired under the apartheid oppressive government era. During this era, the South African educational system was characterised not only by segregation, but by a curriculum that was explicit in enforcing different educational opportunities for South Africans, depending on their racial classification. Within the apartheid educational system, the curriculum of the oppressed was designed by the oppressors who had a cultural background different to that of Africans. Evidently, such an education system was not relevant to their needs nor reflective of the diverse backgrounds of African communities. Subsequently, this article examines the trends and patterns that can be observed in previous studies that address decolonisation and Africanisation of curriculum in South Africa. The article further focuses on the extent and ways in which gender-sensitive curriculum has been implemented in democratic South Africa. The article is based on studying literature and analysing if, and to what extent, social inclusion and social justice is advanced in its discussion. The analysis indicates that although there is common agreement within the studied literature for the need to decolonise and Africanise the curriculum, the two processes tend to move at a snail's pace in South Africa. With regard to the implementation of a gender-sensitive curriculum, literature reveals that good policies that have sought to implement gender equality in education are put in place; however, they lacked implementation. 
Keywords: Curriculum Transformation, Right and Access to Education, Africanised Curriculum, Gender Sensitivity

\section{Introduction and Background}

Africanisation, decolonisation, and gender sensitive curriculum are the key concepts discussed in this article. We begin this conceptual discussion with a brief review of the already listed concepts. Specifically, this article argues for the decolonisation of the curriculum in order to achieve Africanisation and gender sensitive curriculum for equity and social justice. Considering the scope of the discussion, it is important to demonstrate how decolonisation and Africanisation are linked, to achieve a socially just curriculum. In addition, the thesis of this article is that the recognition of the right to education should be inclusive of a right to a curriculum that acknowledges the essence of a people, is gender sensitive, and incorporates what Cohen (2010:84) asserts are a range of social citizenship rights. Thus, the focus is on the progress that has been made in realising that dream, which we regard as a right to 'an Africanised and gender sensitive human rights-nuanced curriculum owed to South Africans'. Taking cues from Mwinzi (2016: 377), we examine the historical context for educational equity in the post-apartheid South Africa. We adopt a position that it is crucial to decolonise, Africanise and gender sensitive education structures and the curricula as a means of 'reclaiming indigenous African voices through curriculum reforms and the transformation of education discourses at all realms, including education' (Mwinzi 2016: 377). Hence, this article's submission is that the inclusion of local and indigenous knowledge systems in the South African education system, and an explicitly gender sensitive curriculum within higher education is necessary to make education relevant to the communities it is supposed to serve. We hold that such a focus would be the embodiment of a socially just curriculum, which is a human right and should be gender sensitive, reflect experiences, belief systems and social realities of the people for whom it is intended and whom it should serve. Employing social inclusion and social justice theories, the article is based on studying literature and in turn analysed impediments to the fulfilment of rights to a gender sensitive and an Africanised curriculum.

Before 1994, South African schooling was divided into several subsystems along racial and ethnic-linguistic lines, with the unequal provision of 
resources by the apartheid government. For example, there were schools for Blacks, Whites, Coloureds, and Indians. During this era, the schooling system in South Africa was characterised by segregation and unequal institutions which existed within the country. This kind of education was quite explicit in enforcing different educational opportunities for South Africans, depending on their official racial classification. Most Black people were offered an inferior education known as Bantu Education. According to Nyoka, Du Plooy and Henkeman (2014: 5),

the Bantu Education system robbed the largest section of the population, particularly, blacks, of basic skills such as critical thinking and problemsolving and, instead, equipped them with substandard education that effectively confined them and, in all likelihood, the following generation to a life deprived of the most basic of human rights.

Thus, education was used to under-develop blacks and in the process, through an unjust system, deprived them of their educational human rights. Nyoka et al. (2014) posit that the perpetuation of the stereotype that intelligence and development are the domains of whites and that blacks are largely uneducated and inferior was rife during this period. Msila (2007) points out that before 1994, South African schooling was divided into several subsystems along racial and ethnic-linguistic lines, with unequal provision of resources by the state. Hence Msila's (2007) assertion that apartheid education (Bantu Education) was used as a tool to divide society as it constructed certain forms of identity among learners. Msila further states that these divisions reinforced the inequalities of a divided society. Similarly, Spreen and Vally (2010) describe the Bantu Education era as the most racially skewed education system in the world. They further state that schooling was meant to inculcate and naturalise an ideology of racial separation among the country's different races. It is against this background that there has been a need to transform the education system and the curriculum in postapartheid South Africa, to cater for all learners regardless of their ethnicity, socio-economic status, abilities, and gender.

Reflecting on education systems in Africa, Mwinzi (2016) declares that even after many years of self-rule and independence, African countries have not succeeded fully in empowering Africans through enabling them to determine their own indigenous African educational framework. Focussing on South Africa, Mahabeer (2018: 1) argues that, 'over 21 years into democracy and the 
commitment for radical transformation in education, South Africa continues to adopt and adapt international imperatives and standardization in pursuit of first world rankings', despite the fact that decolonisation of the curriculum has become a buzz word. However, current research, for example, Ramrathan's (2016: 3), declares that,

current transformation in South African higher education is missing the point, and Westernised Eurocentric paradigms continue to be embedded in African communities and more innovative ways of intellectualising the curriculum are needed.

Similarly, decrying this status quo, Horsthemke (2017) is of the view that decolonisation of the curriculum is caught between the local (Africanisation, indigenisation) and the colonial (Western, imperial, Eurocentric), and internalisation and globalisation. Also, supporting this view, Letsekha (2013: 8) states that,

while some institutions of higher learning have made strides in contextualising their pedagogical structures, curricula still exist that privilege Western ways of knowing despite the space allowed by the new constitution for retooling educational discourse.

This article, therefore, explores the ground already covered to Africanise, decolonise, and efforts made to implement gender sensitive curriculum, for and social justice. Hence, we pose the following questions in this article:

- What trends are observed in the studied literature that address the decolonisation and Africanisation of curriculum in South Africa?

- How is the need for a gender-sensitive curriculum addressed in the literature that focuses on gender equity in South Africa?

\section{Decolonising the Curriculum}

Based on the above context, several scholars have declared the need to decolonise education (Horsthemke 2017; Mahabeer 2018; Leboloane 2018, Zeleza 2009). The decolonisation of the curriculum within the higher education system in South Africa, according to Zeleza (2009) should call for the 
dismantling of Eurocentric epistemologies that continue to dominate the curriculum. For Heleta (2016), Langdon (2013) and McKaiser (2016) decolonising the curriculum should involve exposing colonial and discriminatory legacies, in order to eradicate inequalities in the production of knowledge. On the other hand, scholars such as Mbembe (2015) are of the view that decolonising the curriculum is not about shutting down Eurocentric and Western worldviews and traditions but positioning Africa at the core of the curriculum space. This view is equally supported by Appadurai (2015) who pointed out that the decolonisation of the curriculum is a complex conversation with the colonial past and that it is not merely about the undoing of colonial heritage traditions, and practices that are embedded in all aspects of public life such as the arts, languages, socio-economics, politics, and education. Also supporting this view is Adesina (2006: 44) who avers that,

in South Africa the task of creating a curriculum that is fit for the post1994 era should be about opening the space for diverse ontological narratives, not to insist on erasure or a Euro-ethnic mono-discourse.

Thus, to Adesina (2006), Appadurai (2015) and Mbembe (2015), decolonising the curriculum does not mean throwing the baby out with the bathwater but finding space for African context in the curriculum. We believe that these authors' views are motivated by the concept of globalisation where South Africa serves as one of the key players. Therefore, the position that a curriculum that focuses only on the local content might jeopardise South Africa's position in the global world.

Different scholars recommend different strategies to decolonise the curriculum in South Africa. For example, Heleta (2016) and McKaiser (2016) believe that decolonising the curriculum involves exposing colonial and discriminatory legacies towards eradicating inequalities in the production of knowledge. For Leboloane (2018) the starting point in decolonising the curriculum is in the schools and classrooms which he regards as the formal education laboratories for equity and social justice in a just society. This view is supported by Archer-Ngadi (2019) who mentions that higher education is often celebrated as an engine for development in Africa. However, Naidoo (2008) has raised concerns about the underlying assumptions and unintended consequences of celebrating higher education as the powerhouse for development. Naidoo cautions that outside of the specific context of policy pronouncements, there is 
very little empirical or theoretical work which contributes to a critical academic understanding of the relationship between higher education and development.

In order to decolonise the curriculum for equity and social justice in South Africa, Smith (1991) identified the following elements of decolonisation, i.e. deconstruction and reconstruction, self-determination and social justice, ethics, language, internalisation of indigenous experiences, history, and critique. On the other hand, Chilisa (2012) and Poka Laenui (2000) offer five phases to the process of the decolonisation of the curriculum. These are: rediscovery and recovery, mourning, dreaming, commitment, and action. What is common between these strategies is that the decolonisation of the curriculum in South Africa should mean redressing the imbalances of the past so that the new curriculum is relevant to the social and historical realities of the communities in which tertiary institutions should function. Some literature posit that the FeesMustFall campaign added other ways through which the tertiary institution curriculum could be decolonised (Council on Higher Education; Lebeloane 2018; Mahabeer 2018; Mayaba \& Ralarala 2018). Kamsteeg (2016) mentioned that while the main reasons for the FeesMustFall campaign were generally around access and fees, the lack of diversity, and slow transformation within the merging higher education cultures in South Africa, during this campaign, students added their voice to the slow-moving pace of the decolonisation of the curriculum.

\section{Africanising the Curriculum}

Letsekha (2013) describes Africanisation as a renewed focus on Africa and entails salvaging what has been stripped from the continent. In addition, Letseka points out that Africanisation can be viewed as a call to adapt curricula and syllabuses to ensure that teaching and learning are adapted to African realities and conditions (2013:9). The view about the importance of the context in the process of Africanisation is supported by many scholars. For example, Van der Westhuizen, Grevel and Beukes (2017) argue that Africanisation informed by context should result in decolonisation. We therefore believe that the concept of a context goes hand in hand with the Africanisation process. In a South African context, the Council on Higher Education (2017) submit that incorporating indigenous knowledge systems within the curriculum is one way of understanding the Africanisation process as it implies that South Africans move towards an understanding of their context. Hence, in their 2017 report, the 
Council on Higher Education (CHE) declares that,

Africanisation of curricula implies that education and training as well as praxis (should) be informed by the reality of the South African context, the viewpoints of the people of South Africa and their descriptions of what is needed to build a just society.

The importance of taking cognisance of the context during the process of Africanisation is also acknowledged by Louw (2010) who believes that higher education must focus on the rebirth of an African voice and identity. Concurring with the CHE and Louw, Naidoo (2016: 2) states that Africanisation refers to a 'renewed focus on Africa, a reclaiming of what has been taken from Africa and forms part of a post-colonialist and an anti-racist discourse'. Naidoo further points out that Africanising the curriculum involves developing scholarship and research established in African intellectual traditions. Such education, that embodies African intellectual traditions, is envisaged to produce people who would not be distant from their communities and are sensitive to the challenges facing Africa. We believe that Africanising the curriculum in South Africa would equip students to identify and solve socio-economic problems, like poverty and inequality that face South Africa. It is in this regard that Moulder (1995: 7) identified several components of elements that should form part of Africanising universities. These include but are not limited to, changing the composition of academic, student, and administrator bodies, changing the curriculum and changing the criteria that would determine what should constitute excellent research. Along the similar vein, Van der Westhuizen, Grevel and Beukes (2017) argue that decolonising through Africanisation means removing the aspects that prevent Africanised knowledge and skills from developing as well as towards the exploration of indigenous knowledge and skills to build an empirically sound framework from which to develop academic material.

Hortsthemke and Enslin (2009) believe that Africanisation is inclined to abandon any external influence, such as Western, colonial and Eurocentric influences, with a renewed focus on African cultures, values, and identities. Similarly, Nkoane (2006: 51) maintains that to counter the Eurocentrism of universities, Africanised education should reflect the African beliefs, values, and practices. Such a change is tantamount to Africanising the South African university so that the African students are exposed to the curriculum that is relevant for their continent. Reflecting on South Africa, Le Grange (2016) 
laments that the Africanisation of education and the curriculum is an overdue conversation, considering the unchanged and unopposed Western influence on many South African universities. According to the Council on Higher Education (2017), the main issue identified with respect to curriculum at institutions of higher learning is that,

most modules and/ or academic programmes (such as education, science, law, psychology, sociology, political science) in different disciplines at African universities, are not linked to African cultures and realities.

In this regard, the Council on Higher Education thus makes the following suggestions in order to disrupt the status quo: i.e. changing not only what is taught but how it is taught and increasing access to knowledge; changing understandings of knowledge and whose knowledge it is, and changing who is teaching/researching the said knowledge.

Also contributing on the need for the Africanisation of the curriculum in South Africa, Msila (2009) posits that the process of the inclusion of the indigenous knowledge systems provides the background of Africanising education institutions with an aim not to eliminate modern education in favour of Africanising education, but to add African epistemology in the form of indigenous knowledge systems in order to enhance modern education. As such, our belief is that the inclusion of the indigenous knowledge systems in the South African education curriculum is paramount (Meyiwa \& Maseti 2015) if the aim is to make education relevant to societal and continental experiences. Mwinzi (2016) defines indigenous knowledge systems as the totality of a local set of worldviews which is unique to a given culture or society. On the other hand, Nkoane (2002) interprets an Africanised educational system as one which maintains African awareness of social order and rules by which culture evolves, fosters the understanding of African consciousness, facilitates a critical emancipatory approach to solve the problems of their lives, and produces the material and capacities of Africans to determine their own futures. Concurring with Nkoane (2002), Mwinzi (2016) argues that Africanising curricula is important in order to repeal the distorted view that Africans possess little or no indigenous knowledge of value that can be utilised in the process of educational transformation. In this article, we express the belief that the relevant curriculum for the African child is the one who speaks to the experiences of learners, and reflects the philosophical and social realities of their communities. Equally 
crucial to reflect about the learners' experiences is their differential experiences as female and male beings.

\section{Gender Sensitive Curriculum}

Gender inequality remains a major barrier to human development. Even though girls and women have made major strides since 1990, they have not yet gained gender equality (Koseoglu, Ozturk, Ucar, Karahan, Bozkurt 2020). Aikman and Unterhalte (2005: 3) describe gender equality as aligned to the process of equity which entails respect for human rights and a set of ethical demands for securing the conditions for all people, men and women, to live a full life. They further state that gender equality requires the removal of deeply embedded obstacles and structures of power and exclusion, such as discriminatory laws, customs, practices, and institutional processes, all of which undermine opportunities and outcomes. With regards to gender equality in education in the South African context, formal education terrain today has undergone several modifications since 1994 when the new education system was introduced to replace the old system under the apartheid regime. This new education system sought to redress the imbalances of the past. To achieve this goal, the Department of Basic Education formulated policies to prioritise gender issues (Memela 2017) and in turn integrate them within the curriculum. As part of transforming the education system, a gender-sensitive curriculum was introduced in South Africa. According to UNESCO (2015), a gender-sensitive curriculum should promote equal treatment between men and women and between girls and boys and should encourage them to achieve their full potential. This includes how boys and girls are depicted in textbooks. Creating gender-sensitive curricula entails the incorporation of gender perspectives and epistemologies within the course content and related activities. However, most higher education curricula are beset with gender bias, influenced by socially constructed traditions that ascribe roles to women and men (Leathwood \& Read 2009: 19). It thus becomes crucial to explore the ground covered by the South African government and the higher education system in this regard.

The findings of the studies that sought to evaluate the implementation of gender-sensitive curriculum in South Africa are mixed. For example, Moletsane (2005) reflected on the reasons that 10 years after Beijing, gender inequality, particularly against girl children, persists in the South African education system. The results of her study revealed that South Africa has failed to implement 
gender equality in the education of the girl child. This failure is attributed partly to,

educational factors such as the lack of resources, skills, appropriate educational infrastructure, and a lack of adequate reconceptualisation of curricula content and pedagogy in the schooling and tertiary education system (Moletsane 2005:).

Wadesango, Rembe and Chabayo's 2011 study examined the implementation of gender equality policies in schools in South Africa. The results of their study indicated that boys and girls had equal access to the school system and that most of the learning materials in the selected schools were gender sensitive. However, they observed that classroom practice continued to favour boys and marginalised girls.

Such an observation is of concern considering that South Africa has developed good policies that seek to address gender inequality in education, a concern that is explored in a study by Cekiso (2013) that found that as early as during the foundation phase, reading material expose children to gender stereotyped traditions without challenging and discouraging them. Hence, Nabbuye's (2018) declaration that gender-sensitive pedagogy promises that all learners have equal opportunities to learn while at the same time eliminating gender stereotypes. Flowing from Nabbuye's statement thus, inadvertently, gender-sensitive teachers using a gender-sensitive pedagogy support learners in questioning traditional gender roles and attitudes. Although many studies in South Africa focus on equity in education as it pertains to access to education for all races (Cohen 2010; Mestry 2017; Mzangwa 2019; Sehoole \& Phatlane 2013; Singh 2014; Soudien, Motala \& Fataar 2013) very little is known about gender sensitive curriculum and its implementation (Moletsane 2005; Wadesango, Rembe \& Chabaya 2011; Meyiwa \& Maseti 2015). Indeed, more poignantly, the higher education sector reflects a reality that is bemoaned by this suite of authors. Mihajlovic and Hofmann, (nd) are of the view that apart from integrating gender into the content, a gender-sensitive approach should strive to provide equal participation of both women and men. In this way, a gender-sensitive approach to teaching provides equal opportunity to both female and male teaching staff across disciplines and attracts students of different genders (Mihajlovic \& Hofmann, nd). With the focus on gender equity as a democratic ideal for the new education system in South Africa, discussion in this article brings to the fore the 
literature and studies conducted in South Africa on a gender-sensitive curriculum. Specifically, the focus is on the ground already covered and challenges encountered to implement a gender-sensitive curriculum. Simmonds (2017) investigated lived experiences of some South African female teachers. Simmonds' findings revealed that, despite the establishment of gender equality policies, some teachers reported that they still experienced their school contexts as pervaded with patriarchy and sexism, and often fear confronting these traditional discourses. The findings further revealed that some teachers avoided engaging with subject matter that was likely to cause conflict or confrontation because they did not feel comfortable in such contexts. However, there were reports that some teachers have emerged as activists for gender justice and created awareness of injustices. According to Simmonds (2017) these teachers were curriculum leaders who advocated for social change. To Simmonds, a school culture that values inclusive learning and that promotes diversity and social justice is the cornerstone of democratic societies. In South Africa, within the basic schooling system, although there exists gaps and an indication that it necessary to implement and monitor good gender sensitive policies, the higher education sector relatively is lagging in boldly embracing a gender sensitive curriculum (Meyiwa \& Maseti 2015).

\section{Social Justice and Educational Human Rights}

Social justice and educational human rights pertain to both basic and tertiary education in South Africa and the related discussion begins with the focus on basic education. Basic education is one of the focus areas identified by the South African Human Rights Commission in order to fulfil effectively its mandate of promoting, protecting, and monitoring the realisation of Human Rights in South Africa. Therefore, Cohen (2010) points out that access to education is one of a range of social citizenship rights that are intended to afford members of a society an opportunity to share in a basic level of social, economic, and cultural wellbeing and to mitigate societal inequalities. In addition, the South African Human Rights Commission states that access to education means that every child should be able to acquire the necessary knowledge, to live in , and adapt to a rapidly changing world. In addition, Soudien, Motala and Fataar (2013) point out that education access includes learner attendance as well as enrolment, progression at the appropriate age, achievement of learning goals, equitable access to opportunities to learn, and availability of an adequate learning environment. 
Equal access to education as a human right has been confirmed by many organisations, such as the United Nations Declaration of Human Rights (United Nations 1948), Education for All, the United Nations Educational, Scientific and Cultural Organization (UNESCO 1990) and the Millenium Development Goals (United Nations 2000). The common goal among all these organisations is to expand access to education for the marginalised populations. For South Africa, a country that endured an apartheid-based form of education described in the introduction of this article, equal access to quality education is a pressing issue. Thus, as demonstrated by various literature cited in this article, it is crucial that social justice in education entails that all learners should have access to schools of similar quality with an Africanised and gender-sensitive curricula. Decrying the lack of educational access, Mestry (2017) points out that in South Africa the socio-economic status of parents, racial and religious discrimination, high costs of school fees, and schools' language policies, are some of the contributing factors hindering poor learners from accessing basic and quality education. In this article, we follow Lupton (2005: 14) who speaks about 'school processes, such as the standard of teaching, rather than aggregate learner test results, with which it is sometimes associated'.

Based on the above historical context for education equity in South Africa, it is clear that,

the post-apartheid government that came to power in 1994 inherited an inequitable and unjust education system whose expression included preferential access to education (Mestry 2017; Msila 2007; Nyoka, Du Plooy \& Henkeman 2014; Spreen \& Vally 2010).

As such, the new democratic government declared education as one of the key areas that needed transformation. Transforming education would therefore mean that all South Africans had equal right to education. Hence, Fiske and Ladd (2004) and Lewin (2009) are of the view that the South African educational system has made laudable progress in removing barriers that restricted physical access to schooling based on race. However, Motala, Dieltiens and Sayed (2009) while acknowledging that significant progress has already been made toward universal enrolment, argue that this has not altered meaningfully apartheid era patterns of educational inequality. Even in the post-apartheid era, research studies of education continue to document extreme inequalities for education attained by South Africans (Lu \& Treiman 2011). Bunting (2004) concurs by 
claiming that in South Africa, even today, the rich continue to afford and gain access to education whilst the poor majority, consisting mainly of black people, seem not to benefit from the introduction of policies aimed at transforming education. Similarly, Holtzman (2014) states that education remains one of the greatest sites of inequality in South Africa despite the fact that access to education is considered a basic human right. Thus, education in post-apartheid South Africa has become a key site of struggle for social justice.

Available literature on access to education in South Africa has focused on increasing enrolments (physical access) (Lewin 2009; Motala et al. 2007; Shindler \& Fleisch 2007). However, Hill, Baxen, Craig and Namakula (2012) are of the view that efforts to create a just and democratic educational system by removing barriers to meaningful access and participation for all citizens are incomplete. In this article, we align ourselves with this argument which advocates the documentation of the extreme inequalities for education. We move from the premise that social justice in education is not likely to be achieved by opening doors for all citizens without recognition of the context. Specifically, social imbalances within the communities in South Africa are likely to play an important role in the effort for education equity. In other words, the historically unequal distributions of economic, social, and cultural capital in the South African landscape are likely to have a bearing on the efforts to implement equal access to education.

\section{Inequality in Basic Education in South Africa}

McKeever (2017: 114) argues that 'South Africa consistently ranks as one of the most unequal countries in the world, with many arguing that the country represents both a developed and developing country'. He further points out that educational inequality plays an important role in determining most other forms of social inequality both at any moment and over time. Thus, educational differences created during the apartheid era have great importance for understanding continuing inequalities in the new democratic South Africa. Mzangwa (2019) acknowledges the existence of inequality in education access in South Africa and attributes this problem to poor implementation of policy and lack of monitoring in respect of compliance with the current policies, resulting in a decided lack of success in redressing and transforming the educational system. De Kadt (2012) is of the view that in South Africa, extremely high levels of inequality in both the educational system and in society at large make equality 
a pressing issue. Hlalele (2012) also raises the issue of inequity between urban and rural education. He states that 'vast incongruities or inequalities between better-resourced urban communities and neglected rural areas impinge on the provision and access to education' (Hlalele 2012: 121). Similarly, Saugeat and da Graca (2007: 7) state that,

despite all efforts deployed by countries around the world and the vigorous mobilisation of international communities, rural people still lag far behind in education and are particularly hard hit by poverty and hunger.

They further argue that,

in developing countries, the slow progress towards universal education is largely due to sluggish school enrolment and attendance among rural people and the persistence of very low enrolment rates in rural areas (Saugeat \& da Graca 2007: 213).

Tailor and $\mathrm{Yu}$ (2009: 5) trace educational inequalities from 'the hierarchical structure of the society, including access to wealth, prestige and power'. According to them, this hierarchical structure on society was 'created to be on the basis of race through decades and even centuries of institutionalised inequality'. Acknowledging the existence of educational inequality in England, Lupton (2005) compared the quality of education offered in the schools located in the poorest areas and those located in the more advantaged areas. Lupton concluded that schools located in the poorest areas provided lower-quality education than those in more advantaged areas; thus, high-poverty contexts exert downward pressures on quality (Lupton 2005). A similar trend has been observed in South Africa. For example, Nyoka, Du Plooy and Henkeman (2014) argue that in South Africa, the type of education an individual has access to, is largely proportional to one's socio-economic status and race. Theycontend that the 'wounds of the past impact the present' Nyoka, DuPlooy and Henkeman (2014: 14). They support this statement by arguing that policy decisions in education taken after 1994 have often perpetuated racial divides and contributed to the widening gap between rich and poor that in many instances still runs across racial lines. Hill, Baxen and Namakula (2012) avert that the enduring impact of the apartheid's legacy on education in the new democratic South Africa is evidenced 
by the fact that the majority of black learners still attend schools that have inadequate resources. Ndimande (2009) also blames the shortage of resources in the township and rural schools to the apartheid legacy. He further points out that the shortage of resources in these schools contributes to their dysfunctional operation and that the lack of resources in these schools has forced the black parents to resort to transferring their children from poor township and poor rural schools to wealthy schools in the suburban school areas. This situation has a negative effect on South Africa's dream for equal access for all learners to quality education. Fataar (2017) argues that differential educational opportunities lead to differential educational outcomes and differential labour market opportunities. According to Fataar, this pattern often reproduces the privileges and inequalities of groups in a society so that those at the lower end continue to remain within the poverty and inequality trap. On the other hand, Holtzman (2014) concurs by viewing this situation as perpetuating historical disadvantage and deepening inequality with education becoming a key site of struggle for social justice in post-apartheid South Africa. De Kadt (2012) states that the poor quality of most of the public education in South Africa is a major injustice while Maddock and Maroun (2019) conclude that the South African schooling system is still characterised by unevenness and inequality.

\section{Inequity in Higher Education in South Africa}

Even though South African universities have moved from an elite, racially divided educational system to one that is more democratic and representative of the country's demographics, they still face numerous challenges (Pather 2015). Research into student access to higher education emphasises the fact that access does not necessarily guarantee meaningful social and academic engagement, levels of retention and/or attainment of success (Morrow 2009; 78). According to Pather, Norodien, Cupido and Mkonto (2017: 162), 'it is a common understanding that students enter South African universities from positions of extreme inequality in terms of schooling, race, class, and socio-economic resources'. The results of a study conducted by Bazana and Mogatsi (2017) revealed that institutional cultures in historically white universities alienate and exclude black students' identities. The black students' culture, heritage, language and tradition, and, consequently, self-esteem and self-concept, is altered in these institutions (Bazana \& Mogatsi 2017).

In their study on multilingualism, Mayaba and Ralarala (2018) raised 
concern about the South African government's failure to implement multilingualism at tertiary level. One of their findings was that students were questioning the hegemony of English, the slow pace at which universities were implementing multilingual policies, and lack of clarity on the positioning of African languages as languages of learning and teaching. This concern was based on the fact that the majority of students in South African universities were being taught in a language (in most cases, English) which was not their mother tongue. This situation is a recipe for educational inequality since those students whose mother tongue is English are at an advantage. The issue of the medium of instruction at tertiary institutions in South Africa is also raised by Lafon (2009). He argues that,

the role of the language of teaching and learning has not received sufficient attention as a factor denying access to education in South Africa, and yet the majority of underperforming learners are children who learn in a language that is not their mother tongue and yet language remains a determining factor in educational access among African learners in South Africa (Lafon 2012).

Acknowledging educational inequity in South Africa, Badat (2010) points out that social, politica, 1 and economic discrimination and inequalities of a class, race, gender, and institutional and spatial nature profoundly shaped, and continue to shape, the South African Higher Education.

\section{Analysis and Discussion}

Examining the studied literature, we focused on what the South African educational system has achieved, and the challenges encountered. We observe that about a decade after the end of the apartheid era in South Africa, i.e. 2004, a significant number of scholars began studying and writing intently on decolonising and Africanising the curriculum. Specifically, as South Africa is changing gradually socially and politically, many scholars (e.g. Badat 2010; Bazana \& Mogotsi 2017; Msila 2007; Ndlovu-Gatsheni 2018) see education as a vehicle for improving aspects of the political, social, and economic landscape. Analysis related to Africanising and presenting a gender-sensitive content within curricula are presented in the following discussion, set in the following thematic foci: 


\subsection{Need for Decolonising the Curriculum}

In its global responsibility to promote global peace and respect for human rights, and, through its agency, UNESCO, has facilitated with its member states processes that demonstrate human rights through educationalsystems. The literature cited in this article (e.g. Ndlovu-Gatsheni 2018; \& Nkoane 2006) reverberate UNESCO's resounding call for global citizenship education and to entrench human rights by intently decolonising the curriculum in South Africa. At the core of this call is the dismantling of Eurocentric epistemologies that continue to dominate the curriculum which the discussion of this article, citing various literature, regards as involving a process of exposing colonial and discriminatory legacies. As portrayed in Bunting (2004) and Mbembe (2015), it is asserted that the process of decolonising the curriculum serves as a contributing factor towards eradicating inequalities in the production of knowledge. Ndlovu-Gatsheni (2018) in a seminal piece of work entitled 'Epistemic freedom in Africa: deprovincialization and decolonization' argues that the inherent dignity of the African people should be resuscitated through ensuring that the content of curricula is based on their experiences and content. Hence, Ndlovu-Gatsheni's assertion and reference to a decolonised curriculum as a process: 'cognitive justice'.

Concurring with Ndlovu-Gatsheni's line of thought and analysis, we hold that the decolonisation of the curriculum serves as one of element in a process of liberating the African epistemology, thereby endorsing Africa's existence, ways of knowing and interpreting knowledge in Africa's terms. However, as pointed out by Adesina (2006) and Msila (2007), there is acknowledgement that decolonising the curriculum is multifaceted and complex as colonial heritage traditions and practices are embedded in all aspects of public life such as the arts, languages, socioeconomics, politics, and behavioural patterns. Hence, these authors' bold assertion that a curriculum that focuses only and essentially on the local content might compromise diversity. Indeed, an ideal curriculum is the one that finds a balance among a plethora of worldviews but with an upper hand of African epistemologies. This approach is supported by UN (2000) and UNESCO (2015) wherein there is pursuit for global citizenship education that affords respect for all kinds of educational knowledge.

\subsubsection{Strategies for Decolonising the Curriculum}

While we acknowledge the calls and pursuits that are presented in the above sec- 
tions, we hold that the decolonisation of the curriculum within the higher educational system in South Africa should be a conscious effort, with a purpose that exposes colonial and discriminatory legacies. We subscribe to a process that would decolonise the curriculum for equity and social justice in South Africa, that prioritises, among others, elements of decolonisation; deconstruction and reconstruction, self-determination and social justice, ethics, language, internalisation of indigenous experiences, and a forgotten history, as espoused by Smith (2011). We also find Chilisa (2012) and Poka Laenui's (2000) suggested five phases to the process of decolonisation of the curriculum which are ideal and practical; i.e. rediscovery and recovery, mourning, dreaming, commitment, and action. For these authors' suggestions to make a significant impact, any strategies intended to decolonise the curriculum in South Africa should not lose sight of redressing socially constructed gender imbalances, an element of discussion that is further explored hereunder.

\subsection{Need for Africanising the Curriculum}

We find that there has been work already covered to Africanise the curriculum, described by several authors as a renewed focus on Africa which involves reclaiming what has been stripped off from the continent. Of note is this set of literature, i.e. Mbembe 2015; Heleta 2016; Ramrathan 2016 \& Archer-Ngadi 2019. These scholars exalt the need for Africanising the higher education curriculum but equally point out that it would be necessary beyond the content, that teaching and learning methods ought to be decolonised, as well as recognised that the curriculum should not be oblivious to the learners' context.

Further, the significance of acknowledging context in the process of Africanisation is an element of focus and discussion that is crucial for reclaiming African identity and worth, an assertion that is well captured in NdlovuGatsheni's (2018) discussion of transforming knowledge and the curriculum that is consumed by Africans. In order to leapfrog in transforming curricula, we hold that assertions like this one of Ndlovu-Gatsheni should be coupled with a passion of providing tangible proposals of replacing curricula that is laced with Eurocentric knowledge. Hence, our appreciation of the literature (e.g. Meyiwa \& Maseti 2015 and Horsthemke 2017) that brings to the fore the fact that the use of and accommodating indigenous knowledge systems ought to be one way of the tenets in the Africanisation curriculum process; equally, and as a form of taking cognisance of lived realities and the context of the South African 
previously marginalised people. What these scholars point out, echoes Mahabeer (2018) \& the Council on Higher Education's (2017) assertion that curriculum is touted as a significant tool to contribute towards recognising the existence of such a people.

While we applaud the above discussion, we find that the studied literature does not provide bold steps and strategies of implementing the great conceptual ideas and underpinnings of the decolonised curricula. To ensure that there is real change of the good ideas, guidance on the providing policy, and programmatic directions for beneficial implementation is significant. Providing clear guidance on integrating Africanised curricula and global citizenship education in an educational system is crucial.

\subsection{Need for a Gender sensitive Curriculum in South Africa}

The discussion of this article has highlighted the need to have a curriculum that is sensitive and reflects on gender inequalities and lack of gender equity within our society, as observed by Aikman \& Unterhalter 2005; Moletsane 2005 and Simonds 2017 among others. The lack of such sensitivity is a major contributing barrier to human development, argue scholars presented in this article, who moan the reality that notwithstanding the fact that the female folk have made a significant contribution to the development of the country, achieving gender equity is farfetched. While acknowledging that the country's educational system has several modifications since the onset of the democratic dispensation in 1994, gender inequalities within the new educational system remain intact as was the case with the old system under the apartheid regime. Although the new education system has pursued redress, gender redress and the related imbalances of the past continue to plague the curriculum. To achieve a gender sensitive curriculum one of the goals should be an outright intent to formulate and prioritise policies that focus on addressing gender inequalities within the curriculum, aptly expressed by Cekiso (2013) as inclusive of the manner in which boys and girls are depicted in textbooks. While Cekiso's and Wadesango, Rembe, \& Chabaya's work focus on the importance of addressing the gender imbalances within the basic education phase, Meyiwa \& Maseti (2016), Memela (2017), and Simond (2017) s' foci are on achieving gender equity within the higher education sector. We hold that it is crucial to formulate curricula that is not only gender-sensitive but curricula that challenge equally and intently gender perceptions and epistemologies that undermine women and girls' roles within the South African society. 


\subsection{Social Justice and Educational Human Rights}

Access to basic education and tertiary education are regarded as social justice and human rights in this article. The discussion concurs with the South African Human Rights Commission (SAHRC) and UNICEF South Africa's (2011) stance that this set of human rights fall within SAHRC's key responsibility - their responsibility - to ensure they promote, protect, and monitor, the actualisation of human rights in South Africa. Accordingly, access to education is a crucial social citizenship right, which contributes immensely towards a country's social and economic ... and in turn alleviates societal inequalities. The democratic political administration in South Africa acquired a myriad of inequalities inclusive of which were gender inequalities, a status quo pointed out by Aikman \& Unterhalter (2005), Wadesango, Rembe \& Chabaya (2011), and Memela (2017). We are of the firm belief that the curricula could play a significant role and could become a catalyst as a vehicle of addressing educational as well as some societal inequalities.

\section{Conclusion}

This article has presented the significance of a curricula and content that honours knowledges and ways of knowing of the African people. Referring to such a project as a process of decolonising and Africanising the subject content presented to various levels of the educational system, we argue that the decolonisation of the curricular is, in essence, a human right and a social justice issue. Further, there is caution against an Africanised curriculum that is devoid of women and girls' experiences and outlook. This article has thus demonstrated that although various authors may have different interpretations of what should constitute decolonising and Africanising the curricula, there is convergence in the assertion that, despite South Africa's progress towards realising the right to education in post-apartheid South Africa, this journey has been problematic and slow. While there is consensus that the country should celebrate the achievement of educational access, however, educational access without educational success is not enough. We argue that aside from the fact that South Africa ought to find the balance between the two, that is access and success, lack of a gender sensitive approach towards the curricula as well as policy implementation, monitoring and unequal socio-economic status could pose major challenges for the achievement of an ideal Africanised educational system in South Africa. It is to this end that we hold that it would only be through a vigorous process of addressing a legacy 
of extreme inequalities within South Africa's educational system that the ideal of a socially just and gender sensitive truly Africanised curricula would be realised.

In summary, the literature we presented in this article has brought to light several inequalities, and accentuates the fact that the country's educational system requires extensive redress in order to move away from reflecting within its curricula elements of what was meant to engrain colonisation - and move towards portraying content that is meant to liberate. Alongside this pursuit, we acknowledge gaps within the literature, i.e. lack of clear strategies to decolonise the curriculum, proposals of accelerating transformation, as well as identifying advance barriers to transformation. We hold that it is crucial to provide concrete suggestions of translating concepts and challenges discussed in the literature into practical, detailed, Africa-nuanced topics and curricula objectives in a way that acknowledges African contexts and experiences.

\section{References}

Adesina, J.O. 2006. Sociology beyond Despair: Recovery of Nerve, Endogeneity and Epistemic Intervention. South African Review of Sociology 37, 2: 241 259.

Aikman, S. \& E. Unterhalter 2005. Introduction. In Aikman, S. \& E. Unterhalter (eds.): Beyond Access: Transforming Policy and Practice for Gender Equality in Education. Oxford, UK: Oxfam.

Appadurai, A. 2015. Playing with Modernity: The Decolonization of Indian Cricket. Altre Modernita 14: 1 - 24.

Archer-Ngadi 2019. UNIZULU Symposium 2 October 2019. On Dissecting Africanisation of the Curriculum. Available at:

http:www.unizulu.ac.za/unizulu-dissects-africanisation (Accessed on 15 August 2020.)

Badat, S. 2010. The Challenges of Transformation in Higher Education and Training in South Africa. Paper Commissioned by the Development Bank of Southern Africa. Available at:

https://www.ru.ac.za/...The\%20Challenges\%20of20Transformation\%20in \%20High (Accessed on 15 July 2019.)

Bazana, S. \& O.P. Mogotsi 2017. Social Identities and Racial Integration in Historically White Universities: A Literature Review of Social Identities 
and the Experiences of Black Students. Transformation in Higher Education 2, 0: 1 - 13.

Bunting, I. 2006. The Higher Education Landscape under Apartheid: In Cloete, N.P., R. Maassen Fehnel, T. Moja, T. Gibbon, H. Perold (eds.): Transformation in Higher Education: Global Pressures and Local Realities. Netherlands: Springer.

Cekiso, M. 2013. Gender Stereotypes in Selected Fairy Tales: Implications for

Teaching Reading in the Foundation Phase in South Africa. Journal of Sociology and Social Anthropology 4,3: 201 - 206.

Chilisa, B. 2012. Indigenous Research Methodologies. Los Angeles: Sage Publications.

Council on Higher Education 2017. Decolonising the Curriculum: Stimulating Debate. Briefly Speaking 3, November. Che\%202017.pdf.

De Kadt, J. 2009. Education and Injustice in South Africa. Available at:

https://hsf.org.za-focus-focus-55-november-2009-images-of-justice (Accessed on 22 July 2020).

Cohen, M. 2010. T.H. Marshall's 'Citizenship and Social Class'. Dissent 57,4: $81-85$.

Fiske, E. \& H.F. Ladd 2004. Elusive Equity: Education Reform in Post-apartheid South Africa. Washington, DC: Brookings Institution Press.

Heleta, S. 2016. Decolonizing of Higher Education: Dismantling Epistemic Violence and Eurocentrism in South Africa. Transformation in Higher Education 1, 1: 1 - 9.

Hill, L.D., J. Baxen, A.T. Craig, H. Namakula \& Y. Sayed 2012. Social Justice and Evolving Conceptions of Access to Education in South Africa: Implications for Research. Review of Research in Education 36: 239 - 260. Hlalele, D. 2012. Social Justice and Rural Education in South Africa. Perspectives in Education 30, 1: 111 - 118.

Holtzman, D. 2014. Realising the Right to Education in South Africa: The Role of Civil Society. Cape Town: Centre for Extra-Mural Studies, University of Cape Town.

Horsthemke, K. \& P. Enslin 2009. African Philosophy of Education: The Price of Unchangeability. Studies in Philosophy and Education 28,3: 209 - 222.

Horsthemke, K. 2017. Transmission and Transformation in Higher Education: Indigenisation, Internalisation and Transculturality. Transformation in Higher Education 2, 1: 1 - 9.

Kamsteeg, F. 2016. Transformation and Self-identity: Student Narratives in Post- 
apartheid South Africa. Transformation in Higher Education 1, 1: 1 - 10. Koseoglu, S., T. Ozturk, H. Ucar, E. Karahan \& A. Bozkurt 2020. 30 Years of

Gender Inequality and Implications on Curriculum Design in Open and Distance Learning. Journal of Interactive Media in Education. http://doi.org/10.5334/jime.553

Lafon, M. 2009. The Impact of Language on Educational Access in South Africa.

United Kingdom: University of Sussex.

Langdon, J. 2013. Decolonizing Development Studies: Reflections on Critical

Pedagogies in Action. Canadian Journal of Development Studies 34,3: 384 $-399$.

Leathwood, C. \& B. Read 2009. Gender and the Changing Face of Higher Education: A Feminized Future? Milton Keynes: Open University Press.

Lebeloane, L.D. 2018. Decolonizing the School Curriculum for Equity and Social Justice in South Africa. KOERS - Bulletin for Christian Scholarship 82,3: 1 - 10 .

Le Grange, L. 2016. Decolonizing the University Curriculum. South African Journal of Higher Education 30, 2: 1 - 12.

Letsekha, T. 2013. Revisiting the Debate on the Africanisation of Higher Education: An Appeal for a Conceptual Shift. The Independent Journal of Teaching and Learning 8: 5 - 18.

Lewin, K.M. 2009. Access to Education in Sub-Saharan Africa: Patterns,

Problems and Possibilities. Comparative Education 45: 151 - 174.

Louw, D.J. 2010. Africanisation: A Rich Environment for Active Learning on a Global Platform. Progressio 32, 1: 42 - 54.

Lu, Y. \& D. Treiman 2011. Migration, Remittances, and Educational Stratification among Blacks in Apartheid and Post-apartheid South Africa. Social Forces 89: 1119 - 1144.

Lupton, R. 2005. Social Justice and School Improvement: Improving the Quality of Schooling in the Poorest Neighbourhoods. British Educational Research Journal 31, 5: 589 - 604.

Maddock, L. \& W. Maroun 2019. Exploring the Present State of South African Education: Challenges and Recommendations. South African Journal of Higher Education 32, 2: 192 - 214.

Mahabeer, P. 2018. Curriculum Decision-makers on Decolonizing Teacher Education Curriculum. South African Journal of Education 38, 4: 1 - 13. Mayaba, N.N., M.K. Ralarala \& A. Pinete 2018. Student Voice: Perspectives on Language and Critical Pedagogy in South African Higher Education. 
Educational Research for Social Change 7, 1: 1 - 12.

McKaiser, E. 2016. Epistemic Injustices: The Dark Side of Academic Freedom.

2016 D.C.S. Oosthuizen Academic Freedom Memorial Lecture, Rhodes

University, Grahamstown. Available at:

http://www.Iol.co.za/news/epistemic-injustices-the-dark-side-of-academicfreedom-2029747

Memela, A. 2017. Department of Basic Education on Education and Gender.

Parliamentary Monitoring Group. Available at:

https://pmg.org.za/committee-meeting/23995/ (Accessed on 26 August 2020.)

Meyiwa, T. \& T. Maseti 2015. Developing Sensitivity towards Questions of Gender within Various Academic Disciplines through Feminist Research and Critique. In Okeke, C.I.O. \& M.M. van Wyk (eds.): Educational Research: An African Approach. Cape Town: Oxford University Press.

Mbembe, A. 2015. Decolonizing Knowledge and the Question of the Archive,

Public lecture, University of the Witwatersrand. Available at: https://wiser.wits.ac.za/system/files/Achile\%0Mbembe\%20 (Accessed on 18 August 2018).

McKeever, M. 2017. Education Inequality in Apartheid South Africa. American Behavioural Scientist 61, 1: 114 - 131.

Mestry, R. 2017. A Critical Analysis of the Learners' Constitutional Rights to Basic Education in South African Public Schools. Available at: www.koersjournal.org.za (Accessed on 22 July 2020.)

Mihajlovic, J. \& A. Hofman n.d. Toolkit for Integrating Fender-sensitive Approach into Research and Teaching. Available at: www.Garciaproject.eu Moletsane, R. 2005. Looking Back, Looking Forward: Analysing Gender Equality in South African Education 10 years after Beijing. Agenda 64: 80 $-88$.

Motala, S., V. Dieltiens \& Y. Sayed 2009. Physical Access to Schooling in South Africa: Mapping Dropout, Repetition and Age-grade Progression in Two Districts. Comparative Education 45: 251 - 263.

Msila, V. 2007. From Apartheid Education to the Revised National Curriculum Statement: Pedagogy for Identity Formation and Nation Building in South Africa. Nordic Journal of African Studies 16, 2: 146 - 160.

Moulder, J. 1995. Universities and Africanisation. South African Journal of Higher Education 9, 1: 7 - 8.

Mwinzi, J.M. 2016. Towards the Africanisation of Teacher Education: A Critical 
Reflection. International Journal of Education and Research 4, 9: 377 386.

Mzangwa, S.T. 2019. The Effects of Higher Education Policy on Transformation in Post-apartheid South Africa. Cogent Education 6: 1 - 15.

Nabbuye, H. 2018. Gender-sensitive Pedagogy: The Bridge to Girls' Quality Education in Uganda. Available at: https://www.brookings.edu/wpcontent/uploads/2018/11/Hawah-Nabbuye-FOR-WEBSITE.pdf (Accessed on 10 July 2020).

Naidoo, R. 2008. Higher Education: A Powerhouse for Development in a Neoliberal Age? In Epstein, D. R. Boden, R. Deem, F. Rizvi \& S. Wright (eds.): Geographies of Knowledge, Geometries of Power: Framing the Future of Higher Education. New York and London: Routledge.

Naidoo, M. 2016. Overcoming Alienation in Africanising Theological Education. Theological Studies 72, 1. https://doi.org/10. 4102/hts.v72il.3062

Ndlovu-Gatsheni, S.J. 2018. Epistemic Freedom in Africa: Deprovincialization and Decolonization. London and New York: Routledge.

Nkoane, M.N. 2006. The Africanisation of the University in Africa. Alternation 13,1: $49-69$.

Nyoka, A., E. du Plooy \& S. Henkeman 2014. Reconciliation for South Africa's Education System. Available at: https://elmmagazine.eu/issue-22014/reconciliation-for-south-africa-s-education (Accessed on 12 July 2020.)

Pather, S. 2015. Factors Influencing Teacher Education Students' First-year Experience and Academic Performance. Unpublished D.Ed thesis, Cape Peninsula University of Technology, Cape Town.

Pather, S., N. Norodien-Fataar, X. Cupido \& N. Mkonto 2017. First Year Students' Experience of Access and Engagement at a University of Technology. Journal of Education 69: 162 - 184.

Pilcher, J. \& I. Whelehan 2004. 50 Key Concepts in Gender Studies. London, UK: SAGE.

Poka Laenui 2000. Process of Decolonisation. Available at: http://blogs.eciad.ca/humn-311-s003-2020/2020/02/2 (Accessed on 28 August 2020.)

Ramrathan, L. 2016. Beyond Counting the Numbers: Shifting Higher Education Transformation into Curriculum Spaces. Transformation in Higher Education. Available at: http://dx.doi.or9/10.4102/the.vlil.6 
(Accessed on 28 August 2020.)

Sehoole, C. \& R. Phatlane 2013. Government Reforms in Higher Education in South African Higher Education Steering Mechanism. IIEP-UNESCO Report.

Shindler, J. \& B. Fleisch 2007. Schooling for All in South Africa: Closing the Gap. International Review of Education 53: 135 - 157.

Simonds, S. 2017. Teachers as Curriculum Leaders: Towards Promoting Gender Equity as a Democratic Ideal. Education Research for Social Change 6, 2: $16-28$.

Singh, K. 2014. Right to Education and Equality of Educational Opportunity. Journal of International Cooperation in Education 16, 2: 5 - 19.

Smith, L. 1999. Decolonizing Methodologies: Research and Indigenous Peoples. London: Zed Books.

Soudien, C., S. Motala \& A. Fataar 2013. Introducing the Challenge of Converting Access to Quality in Education. South African Review of Education 18, 2: 3 - 8.

South African Human Rights Commission and UNICEF South Africa Report 2011. South Africa's Children: A Review of Equity and Child's Rights. Available at: www.sahrc.org.za/home/21/files/SApdf (Accessed on 03 November 2020.)

Spreen, C.A. \& S. Vally 2010. Prospects and Pitfalls: A Review of Post-apartheid Policy Research and Analysis in South Africa. Comparative Education 46, 4: 429 - 448.

Taylor, S. \& D. Yu 2009. The Importance of Socio-economic Status in

Determining Educational Achievement in South Africa. A working paper of the Department of Economics and the Bureau for Economic Research at the University of Stellenbosch.

Van der Westhuizen, M., T. Grevel \& J.W. Beukes 2017. 'Are we hearing the voices?' Africanisation as Part of Community Development. HTS Theological Studies 73, 3. Available at:

http://dx.org/10.4102/hts.v73i3.4512

(Accessed on 14 August 2020.)

United Nations 1948. The Universal Declaration of Human Rights. New York, USA.

United Nations 2000. Millennium Development Goals. New York, USA.

United Nations Education, Scientific and Cultural Organisation (UNESCO) 1990. World Declaration on Education for All. Paris, France. 
United Nations Educational, Scientific and Cultural Organization (UNESCO) 2015. Embracing Diversity. Toolkit for Creative Inclusive Learning. Available atL

https://www.Google.com/search?Biw=1920\&biw=1920\&bih=963\&ei= (Accessed on 17 August 2020.)

Wadesango, N., S. Rembe \& O. Chabaya 2011. An Assessment of the Implementation of Gender Equity Policies in Schools in South Africa. The Anthropologist 13,4: 294 - 255.

Zeleza, P.T. 2009. African Studies and Universities since Independence: The Challenges of Epistemic and Institutional Decolonization. Transition 101: $110-135$.

Thenjiwe Meyiwa Deputy Vice Chancellor: Research University of South Africa

Tshwane-Pretoria Email: meyiwt@unisa.ac.za

Madoda Cekiso English Professor Tshwane University of Technology English Department

Tshwane-Pretoria Email: cekisomp@tut.ac.za 